\title{
Strategic Challenges in the Baltic Sea Region - Russia, Deterrence and Reassurance
}

\author{
Ann-Sofie Dahl (red.) \\ Washington DC: Georgetown University Press 2018 \\ 184 sidor. ISBN 9781626165700
}

Recenserad av Karlis Neretnieks [Generalmajor (ret), Kungliga Krigsvetenskapsakademien, Stockholm]

Vill man få en uppfattning om de säkerhetspolitiska utmaningarna i Östersjöområdet bör man ta del av denna mycket läsvärda antologi som i tolv korta uppsatser analyserar ett antal centrala faktorer som påverkar säkerheten i regionen. Det är en imponerande samling experter som redaktören för boken, Ann-Sofie Dahl, lyckats få till att medverka. Tyvärr medger inte utrymmet här att kommentera samtligas bidrag, det hade de förtjänat. Alla har på ett stringent och lättbegripligt sätt lyckats lyfta fram de sannolikt avgörande frågorna inom de områden som de avhandlat.

Här dock några axplock. Gudrun Perssons analys av Rysslands syn på säkerhet och vad denna kan innebära för grannländerna, då inte bara Baltikum, är kanske det bästa som satts på pränt på länge inom detta område. Den visar på ett tänkesätt som till mycket stor del skiljer sig från hur man i väst ser på fred och säkerhet. Ryssland anser sig vara i en pågående konflikt med "västvärlden» och ser sina nationella intressen hotade. Likaså lyfts Rysslands strävan efter en annorlunda världsordning fram. Sammantaget blir slutsatsen att väst inte förstår allvaret i de utmaningar som man står inför.

I sitt kapitel om NATO:s möjligheter att möta utmaningarna diskuterar Christopher Coker de olika prioriteringar, bland annat geografiska, som finns inom alliansen. Men också EU:s otydliga roll som säkerhetspolitisk aktör berörs. Det som dock kanske är mest intressant är hur författaren gör upp med populära och enligt hans mening i praktiken innehållslösa slagord som "smart defence» och "trip wire», om de inte kan backas upp med substantiella militära resurser, "follow-on forces».

Mikael Vedby Rasmussen framför i sitt kapitel om hur avskräcka Ryssland från äventyrligheter i regionen en intressant tes. Rysk hybridkrigföring - som ofta lyfts fram som det allvarligaste hotet mot de baltiska länderna, bland annat därför att det skapar en gråzon där artikel 5 i NATO-stadgan kan bli svår att tillämpa - kanske inte 
är det stora hotet. Det går att vända på problemet. Så länge det inte är öppet krig och Ryssland fortsatt önskar att bedriva sjöfart i Östersjön har väst ett utomordentligt starkt avskräckningsinstrument - nämligen att blockera den ryska sjötrafiken. Det som är betydligt svårare för NATO är att göra det trovärdigt att man kan och avser att med militära medel försvara sina baltiska allierade.

Ett av de stora problemen när det gäller att göra det sannolikt att NATO kan agera med kraft i regionen, och att Ryssland inte tämligen enkelt och med måttlig risktagning kan försätta NATO i en ohållbar situation, är att Sverige och Finland står utanför alliansen. Ann-Sofie Dahl och Karolina Honkanen belyser i sina respektive kapitel den frågan ur svenskt och finskt perspektiv. Båda pekar på ländernas nära samarbete med NATO inom ramen för Enhanced Opportunities Partnership (EOP), och de stora fördelar det samarbetet innebär när det gäller ökad interoperabilitet, kunskap om varandras tänkande och djupare politisk dialog - men det innebär inte några säkerhetsgarantier eller i förväg förberedda gemensamma militära operationer. Här framträder också en intressant nyansskillnad i målsättningen för ländernas samarbete med NATO. I det svenska fallet är det tämligen uppenbart att det är en fråga om att försöka säkerställa möjligheter till hjälp, utan att ta det inrikespolitiska svåra steget att ansluta sig till alliansen. Finland ser partnerskapet mer som ett sätt att stärka den egna försvarsförmågan, även om det självfallet också innebär att förmågan att ta emot hjälp ökar. Kanske är denna något olika syn på nyttan med EOP också en återspegling av ländernas försvarsförmåga: i det svenska fallet ett historiskt sett mycket svagt försvar, i Finland ett relativt starkt eget försvar.

Ett generellt och intressant fenomen i boken är att Tysklands möjligheter och ansvar för att bidra till stabilitet och säkerhet $i$ regionen bara nämns i tämligen abstrakta termer. Så även i sådana kapitel där en ökad tydlighet hade haft ett värde. Tyskland borde vara den självklara leverantören av de "follow-on forces" som flera av författarna efterlyser som en vital komponent i NATO:s förmåga att avskräcka Ryssland från äventyrligheter i Baltikum, men också för möjligheterna att försvara länderna om så skulle behövas. Här går det bara att spekulera i orsakerna. Är man tveksam till att förespråka något som för många, av olika skäl, kan verka oroande att Bundeswehr då i de flesta avseenden skulle bli den starkaste militära organisationen i Europa? Eller tar man för givet att läsarna är så väl insatta i problemet att det därför inte behöver konkretiseras i form av önskvärda förmågor?

I den mån något saknas i boken är det kanske ett kapitel om kopplingen mellan Östersjöregionen och Nordkalotten. En förutsättning för NATO, i praktiken USA, för att kunna agera kraftfullt i hela det nordisk-baltiska området är att förbindelserna över Atlanten och vidare till Skandinavien kan skyddas. Där spelar Norge och Storbritannien en nyckelroll för att hindra de ryska sjö- och flygstridskrafter som är baserade på Kolahalvön att påverka dessa förbindelser. Ett sådant kapitel skulle ha gjort det tydligt att skyddet av Baltikum ställer stora krav på NATO, såväl vad gäller avskräcknings- som krigföringsförmåga även utanför Östersjöområdet. Det skulle också ha gjort det klart för svenska och finska läsare, främst kanske svenska, att 
eventuella hot mot Baltikum även ställer krav på försvarsförmåga på andra platser än bara i de södra delarna av landet och i Östersjön.

Sammantaget: En ytterst läsvärd bok för alla som har det minsta intresse av de säkerhetsproblem som finns, eller kan uppstå, i Östersjöregionen. Trots det lilla formatet, bara 184 sidor, rymmer den gedigna analyser, nya intressanta infallsvinklar och handfasta slutsatser. Som Anders Fogh Rasmussen påpekar i förordet utgör boken ett viktigt bidrag till att öka kunskapen om de utmaningar vilka NATO som allians, och de enskilda länderna i regionen, står inför. 